\title{
Retinol Inhibition of in Vitro Human Neutrophil Superoxide Anion Release
}

\author{
ANUJA SHARMA, JUNE R. LEWANDOSKI, AND JERRY J. ZIMMERMAN \\ University of Wisconsin Children's Hospital, Division of Critical Care Medicine, Madison, Wisconsin 53792
}

\begin{abstract}
Retinol deficiency has been clinically associated with visual impairment as well as altered growth and differentiation of various epithelial cell populations. An additional factor that may be operative in the setting of retinol deficiency is impaired immunomodulation of the neutrophil inflammatory response. Our study demonstrated a concentration-dependent inhibition by retinol of activated neutrophil superoxide anion $\left(\mathrm{O}_{2}^{-}\right)$release. Concentration of drug (retinol) causing $50 \%$ inhibition of initial velocity $\mathrm{O}_{2}^{-}$production $\left(\mathrm{IC}_{50}\right)$ was $42.6 \pm 10.9 \mu \mathrm{M}$. Latter phases of the $\mathrm{O}_{2}^{-}$release reaction displayed significantly lower $\mathrm{IC}_{50}$ values. Similarly, as time of retinol-neutrophil incubation was increased, $\mathrm{IC}_{50}$ decreased. Retinol inhibition of neutrophil $\mathrm{O}_{2}^{-}$did not appear to involve activation/ desensitization, cytotoxicity, or free-radical scavenging mechanisms. Retinol was shown to inhibit intact PMN $\mathrm{O}_{2}^{-}$release even after addition of the respiratory burst stimulus. Moreover, retinol inhibited $\mathrm{O}_{2}^{-}$release in membranes isolated from activated neutrophils. In addition to promoting proper organization and differentiation of epithelial cells, appropriate plasma/tissue retinol levels may also modulate the neutrophil tissue inflammatory response. (Pediatr Res 27: 574-579, 1990)
\end{abstract}

\section{Abbreviations}

BPD, bronchopulmonary dysplasia

CB, cytochalasin B

FMLP, $N$-formyl-methionyl-leucyl-phenylalanine

HBSS, Hanks' balanced salt solution $\left(^{++}\right.$, complete; ${ }^{\text {, }}$ incomplete, without $\mathrm{Ca}^{2+}$ and $\mathrm{Mg}^{2+}$ )

HEPES, $N$-2-hydroxyethylpiperazine- $N^{\prime}$-2-ethanesulfonic acid

$\mathrm{IC}_{50}$, concentration of drug causing $50 \%$ inhibition of activity

LDH, lactate dehydrogenase

$\mathrm{O}_{2}^{-}$, superoxide anion

PK-C, protein kinase $\mathrm{C}$

PMA, phorbol myristate acetate

PMN, polymorphonuclear leukocytes

PMSF, phenylmethylsulfonyl fluoride

SOD, superoxide dismutase

$V_{i}$, initial velocity

$V_{2-3}$, velocity between 2 and $3 \mathrm{~min}$

$V_{4-5}$, velocity between 4 and $5 \mathrm{~min}$

Received September 27, 1989; accepted January 17, 1990.

Correspondence and reprint requests: Jerry J. Zimmerman Ph.D., M.D., H4/ 470 Clinical Science Center, University of Wisconsin Children's Hospital, 600 Highland Avenue, Madison, WI 53792.

Supported in part by a grant from the Thrasher Research Foundation, Salt Lake City, UT (\#2803-8), and the American Cancer Society (\#IN-35-29).
Advances in public health and infant nutrition have essentially eliminated vitamin A deficiency in healthy term neonates living in developed countries. However, in the premature infant with respiratory distress syndrome, retinol deficiency has been postulated to inhibit airway epithelial growth and differentiation and predispose to the development of BPD (1-3). In addition to its other characterized actions (constituent of rhodopsin in the retina, cofactor for growth and differentiation of epithelial, nervous, and bone tissue), vitamin A has been shown to have phagocytic immunomodulatory effects. Because development of BPD is also associated with a pulmonary influx of apparently activated PMN (4-6), it is conceivable that an inadequate PMN immunomodulatory effect might exist in the lungs of malnourished (vitamin A-deficient) infants developing BPD. An unmodulated PMN inflammatory response could result in pulmonary host autoinjury (7). Our study examined the potential of a specific vitamin A metabolite, retinol, to suppress PMN activation as assessed by its in vitro inhibition of $\mathrm{PMN} \mathrm{O}_{2}^{-}$release.

\section{MATERIALS AND METHODS}

Reagents. Cytochrome c (type III), FMLP, CB, SOD, retinol (70\% all trans), DMSO, xanthine, xanthine oxidase, NADPH tetrasodium salt Type I (NADPH), sodium phosphate dibasic, sodium deoxycholate, PMSF, ethylene glycol, sodium azide $\left(\mathrm{N}_{3}\right)$, phorbol 12-myristate, 13-acetate (PMA), Ficoll 400, and HEPES were purchased from Sigma Chemical Co. (St. Louis, MO); $90 \%$ Hypaque-M from Winthrop Laboratories (Des Plaines, IL); and $\mathrm{HBSS}^{++}$and $\mathrm{HBSS}^{=}$from GIBCO Laboratories (Grand Island, NY). All other chemicals were of reagent grade and used without purification.

$P M N$ isolation. PMN were isolated from healthy adult venous blood (anticoagulated by $10 \mathrm{IU}$ of heparin $/ \mathrm{mL}$ ) using FicollHypaque cushion centrifugation (8). Contaminating erythrocytes were eliminated by hypotonic lysis. Cell numbers were quantitated with a cell counter (Coulter Electronics, Hialeah, FL). PMN were initially suspected in $\mathrm{HBSS}^{++}$at a concentration of 10 to $20 \times 10^{6} \mathrm{PMN} / \mathrm{mL}$ and then aliquots made at a concentration of $5 \times 10^{6} \mathrm{PMN} / \mathrm{mL}$. Individual experiments used PMN isolated the same day from a single donor.

Preparation of activated membrane. Purified PMN were resuspended in $\mathrm{HBSS}^{++} / 1 \mathrm{mM} \mathrm{N}_{3}{ }^{-}$. Equal volumes PMN $\left(10 \times 10^{6}\right.$ PMN $/ \mathrm{mL})$ and PMA $(2 \mu \mathrm{g} / \mathrm{mL})$ were incubated separately for 5 min at $37^{\circ} \mathrm{C}$, then combined and incubated for $30 \mathrm{~min}$ at $37^{\circ} \mathrm{C}$, after which an equal volume of ice cold $\mathrm{HBSS}^{++} / 1 \mathrm{mM} \mathrm{N}_{3}{ }^{-}$was added to quench PMN activation. Thereafter, the suspended PMN were centrifuged at $400 \times g$ for $5 \mathrm{~min} ; 4^{\circ} \mathrm{C}$; taken up in $0.25 \mathrm{M}$ sucrose, $1 \mathrm{mM}$ PMSF; sonicated at $20 \mathrm{~W}$ three times for $10 \mathrm{~s}$ each with $1 \mathrm{~min}$ intervals; and recentrifuged at $400 \times g, 5$ min, $4^{\circ} \mathrm{C}$. The resulting supernatant was ultracentrifuged in a SW60 rotor, $30000 \times g, 4^{\circ} \mathrm{C}$ and the pellet taken up in $25 \%$ ethylene glycol, $1 \mathrm{mM}$ PMSF by Potter Elvehjem homogenization followed by sonication, as noted above. Activated PMN membrane could be stored at $-70^{\circ} \mathrm{C}$ for many months without loss of oxidoreductase activity.

Enzyme assays. NADPH oxidoreductase (PMN superoxide 
anion synthetase) initial velocity, continuous enzyme kinetics were followed spectrophotometrically (DU 50 Series Spectrophotometer, Beckman Instruments Inc., Irvine, CA) according to the previously described method (9). Assays were conducted at $550 \mathrm{~nm}$ within microcuvettes, with a total reaction volume of 1 $\mathrm{mL}$ using cytochrome $\mathrm{c}$ as $\mathrm{O}_{2}^{-}$trap. Final concentrations of reactants included cytochrome $\mathrm{c}(100 \mu \mathrm{M}), \mathrm{CB}(0.01 \mathrm{mM}), \mathrm{PMN}$ $\left(0.5 \times 10^{6} / \mathrm{mL}\right)$, retinol $(4.38-70 \mu \mathrm{M})$, and FMLP $(1 \mu \mathrm{M})$ in $\mathrm{HBSS}^{++}$, pH 7.4. DMSO (solvent for stock solutions of PMA and retinol) never exceeded $0.1 \%$ and did not interfere with reaction kinetics. Cytochrome c, CB, PMN, buffer $\left(\mathrm{HBSS}^{++}\right)$ with or without retinol (total volume $0.9 \mathrm{~mL}$ ) were warmed for $5 \mathrm{~min}$ at $37^{\circ} \mathrm{C}$. FMLP $(0.1 \mathrm{~mL})$ was used to initiate the reaction. SOD $(100 \mathrm{IU} / \mathrm{mL})$ was used to detect nonsuperoxide sources of cytochrome c reduction. Enzyme-specific activity was expressed as nmol of $\mathrm{O}_{2}^{-}$released (nmol of cytochrome $\mathrm{c}$ reduced) per min per $10^{6} \mathrm{PMN}$ or per mg of membrane protein. Reaction rates for $V_{i}, V_{2-3}$, and $V_{4-5}$ were determined for each assay. To ascertain if retinol might have had any inhibitory action on $\mathrm{O}_{2}^{-}$ production after PMN had already been activated, oxidoreductase assays were conducted in the usual manner except that another constituent $\left(0.10 \mathrm{~mL}\right.$ of $\mathrm{HBSS}^{++}$or retinol in $\left.\mathrm{HBSS}^{++}\right)$ was added $1.75 \mathrm{~min}$ after reaction initiation. $V_{2-3}$ was compared to $\mathrm{V}_{\mathrm{i}}$ for each series of reactions after correction for reaction dilution ( 1.0 to $1.1 \mathrm{~mL}$ ) was made.

Assay of NADPH oxidoreductase in membrane recovered from activated PMN was similarly performed. The reaction cocktail (1 mL total) contained $100 \mu \mathrm{M}$ each of cytochrome $\mathrm{c}$ and NADPH in $0.05 \mathrm{M}$ HEPES, $1 \mathrm{mM} \mathrm{CaCl}, 1 \mathrm{mM} \mathrm{MgCl}$, $0.05 \%$ DOC, $\mathrm{pH} 7.4$ buffer. Reactions were initiated by addition of $0.10 \mathrm{~mL}$ of the activated membrane in $25 \%$ ethylene glycol, $1 \mathrm{mM}$ PMSF, and followed again as reduction of cytochrome c.

To quantitate possible retinol free-radical scavenging activity, a cell-free $\mathrm{O}_{2}^{-}$-generating system was used, using xanthine $(100$ $\mu \mathrm{M})$ and buttermilk xanthine oxidase (0.005 units) again with cytochrome $\mathrm{c}(100 \mu \mathrm{M})$ as the $\mathrm{O}_{2}^{-}$trap and colorimetric reagent in $0.05 \mathrm{M} \mathrm{HEPES} / \mathrm{HBSS}^{++}$, $\mathrm{pH} 7.5$, total volume $1 \mathrm{~mL}$ (10).

To evaluate possible activation action of retinol on $\mathrm{PMN} \mathrm{O}_{2}^{-}$ production, a PMN $\mathrm{O}_{2}^{-}$-generating system was assembled as above but used retinol $(70 \mu \mathrm{M}, 35 \mu \mathrm{M}$, and $3.5 \mu \mathrm{M})$ instead of FMLP as the reaction initiator.

Cytotoxicity experiments. Possible cytotoxicity due to retinol was assessed with the following protocol. PMN $\left(5 \times 10^{6} / \mathrm{mL}\right)$ were incubated in $\mathrm{HBSS}^{++}$with and without retinol $(8.75 \mu \mathrm{M})$ for $5 \mathrm{~min}$ at $37^{\circ} \mathrm{C}$, stimulated with FMLP for $5 \mathrm{~min}$ at $37^{\circ} \mathrm{C}$, and cooled on ice. Reaction tubes were centrifuged at $200 \times g, 20$ $\min , 4^{\circ} \mathrm{C}$. Supernatants were assayed for $\mathrm{LDH}$, using $50 \mathrm{mM}$ sodium lactate, $5 \mathrm{mM} \mathrm{NAD}$ in $0.05 \mathrm{M} \mathrm{Na}_{2} \mathrm{HPO}_{4}$, pH 7.4 buffer (11). Supernatant $(0.1 \mathrm{~mL})$, the LDH source, was used to initiate the reaction. Change in absorbance was followed spectrophotometrically at $340 \mathrm{~nm}$, for $5 \mathrm{~min}$ at $37^{\circ} \mathrm{C}$. LDH activity was compared with supernatant obtained after sonication of PMN $(20 \mathrm{~W}$, twice, $10 \mathrm{~s}$ each, with $1 \mathrm{~min}$ intervals) followed by ultracentrifugation (SW60, rotor, $100000 \times g, 60 \mathrm{~min}, 4^{\circ} \mathrm{C}$ ).

$\mathrm{PMN}$ incubated as noted above were recovered after centrifugation, resuspended in $\mathrm{HBSS}^{-}$, quantitated and assayed for NADPH oxidoreductase activity. Cell counts and enzyme activities were compared with those obtained from PMN incubated in buffer at $4^{\circ} \mathrm{C}$ for the entire duration of the experiment.

To demonstrate the possible effect of prolonged incubation of cells with retinol, PMN NADPH oxidoreductase was assayed under the following conditions: 1) PMN incubated with buffer for $60 \mathrm{~min}$ at $4^{\circ} \mathrm{C}$, and for $5 \mathrm{~min}$ at $37^{\circ} \mathrm{C}$; 2) PMN incubated with buffer for $60 \mathrm{~min}$ at $4^{\circ} \mathrm{C}$ and with retinol $(8.75 \mu \mathrm{M})$ and buffer for $5 \mathrm{~min}$ at $37^{\circ} \mathrm{C}$; and 3) PMN incubated with retinol $(8.75 \mu \mathrm{M})$ and buffer for $60 \mathrm{~min}$ at $4^{\circ} \mathrm{C}$ and for $5 \mathrm{~min}$ at $37^{\circ} \mathrm{C}$.

Experimental design/data analysis. As noted above, PMN were aliquoted $\left(5 \times 10^{6} \mathrm{PMN} / \mathrm{mL}\right)$ after isolation. This was performed to minimize decay of PMN oxidoreductase activity (repeated resuspension causing cell lvsis). In concentration-re-
Table $1 . I C_{50}$ values for retinol relative to neutrophil NADPH oxidoreductase $V_{i}, V_{2-3}$, and $V_{4-5}$ reaction velocities from five separate experiments

\begin{tabular}{|c|c|c|c|}
\hline \multirow[b]{2}{*}{ Experiment } & \multicolumn{3}{|c|}{ Retinol $\mathrm{IC}_{50}$ values $(\mu \mathrm{M})$} \\
\hline & $\mathrm{V}_{\mathrm{i}}$ & $V_{2-3}$ & $\mathrm{~V}_{4-5}$ \\
\hline 1 & 40.3 & 18.4 & 14.1 \\
\hline 2 & 53.5 & 38.5 & 36.6 \\
\hline 3 & 25.8 & 13.9 & 14.8 \\
\hline 4 & 50.9 & 19.4 & 20.6 \\
\hline 5 & 42.5 & 17.8 & 22.2 \\
\hline Mean \pm SD & $42.6 \pm 10.9$ & $21.6 \pm 9.7$ & $21.7 \pm 9.1$ \\
\hline
\end{tabular}

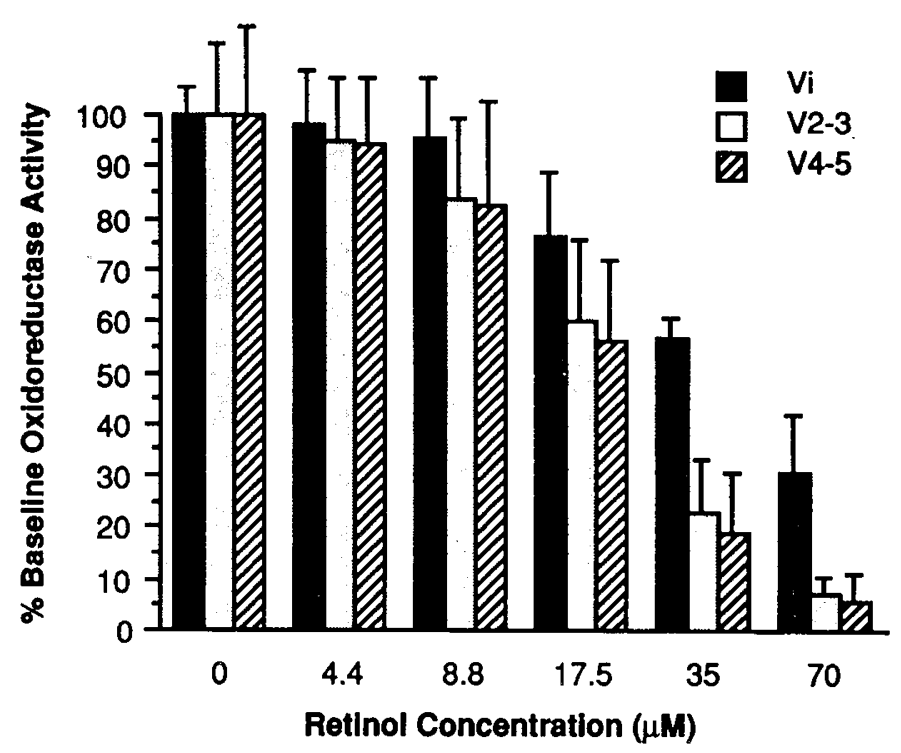

Fig. 1. Concentration-response effect of retinol on intact neutrophil $\mathrm{O}_{2}^{-}$generation induced by FMLP. Differential effects on $\mathrm{V}_{\mathrm{i}}, \mathrm{V}_{2-3}$, and $\mathrm{V}_{4-5}$ are demonstrated. Note that reaction velocities (ordinate) have been normalized to reactions containing no retinol.

sponse experiments, seven identical PMN aliquots were assembled, one for each of the five retinol concentrations examined and one each as an early and late control. Real times of all assays were recorded. In all experiments, control reactions were assayed at the start and end of assays. Although the multiple aliquot technique was used to minimize repeated PMN trauma, a decline in $\mathrm{V}_{\mathrm{i}}$ was noted (mean $\pm \mathrm{SD}=15.2 \pm 6.3 \%$, range $6.4-22 \%, n$ $=5$ ) for the long concentration-response experiments. This wellrecognized spontaneous enzyme decay was corrected for assuming natural logarithmic decay kinetics (9).

All assays represent the mean $\pm \mathrm{SD}$ of $3-4$ determinations. For calculation of $\mathrm{IC}_{50}$, five separate concentration-response experiments were conducted (five retinol concentrations, early and late controls, four assays plus one SOD background for each condition). An equation describing the effect of oxidoreductase activity (ordinate) relative to retinol concentration (abscissa) was fitted by regression analysis for each experiment. $\mathrm{IC}_{50}$ was calculated by solving this equation for retinol concentration when enzyme activity $=50 \%$ of maximum, (i.e. without drug). Traditional approaches using reciprocal plots of $1 / \mathrm{v}$ versus $1 / \mathrm{S}$ at various inhibitor concentrations to derive a true $K_{i}$ are not appropriate in the intact cell system used here, because the concentration of reactants, (e.g. cytosolic NADPH) cannot be precisely controlled.

Statistical analysis of results was made using the $t$ test with the Bonferroni correction for multiple comparisons $(n)$. Significance was assumed when $p \leq 0.05 / n$. 
Table 2. Effect of prolonged incubation of neutrophils with $8.8 \mu M$ retinol on subsequent FMLP-induced NADPH oxidoreductase activity*

\begin{tabular}{|c|c|c|c|}
\hline & A & $\begin{array}{c}\text { Incubation/assay } \\
\text { conditions } \\
\text { B }\end{array}$ & $\mathrm{C}$ \\
\hline & $\begin{array}{c}\text { Incubated } 60 \mathrm{~min}, 4^{\circ} \mathrm{C} \\
\text { w/o retinol; } \\
\text { No retinol in assay }\end{array}$ & $\begin{array}{c}\text { Incubated } 60 \mathrm{~min}, 4^{\circ} \mathrm{C} \\
\text { w/o retinol; } \\
\text { Retinol in assay }\end{array}$ & $\begin{array}{c}\text { Incubated } 60 \mathrm{~min}, 4^{\circ} \mathrm{C} \\
\text { with retinol; } \\
\text { Retinol in assay }\end{array}$ \\
\hline $\mathrm{V}_{\mathrm{i}}$ & $13.15 \pm 0.86$ & $\begin{array}{l}9.88 \pm 1.35 \\
p<0.05: \mathrm{AV}_{\mathrm{i}}\end{array}$ & $\begin{array}{l}7.58 \pm 0.30 \\
p<0.001: \mathrm{AV}_{\mathrm{i}} \\
p<0.05: \mathrm{BV}_{\mathrm{i}}\end{array}$ \\
\hline$V_{2-3}$ & $6.92 \pm 2.03$ & $\begin{array}{l}5.04 \pm 0.98 \\
p \mathrm{NS}: \mathrm{AV}_{2-3}\end{array}$ & $\begin{array}{l}2.69 \pm 0.19 \\
p<0.05: \mathrm{AV}_{2-3} \\
p<0.02: \mathrm{BV}_{2-3}\end{array}$ \\
\hline$V_{4-5}$ & $4.88 \pm 0.89$ & $\begin{array}{l}4.09 \pm 0.88 \\
p \mathrm{NS}: \mathrm{AV}_{4-5}\end{array}$ & $\begin{array}{l}3.04 \pm 0.17 \\
p<0.05: \mathrm{AV}_{4-5} \\
p \mathrm{NS}: \mathrm{BV}_{4-5}\end{array}$ \\
\hline
\end{tabular}

* All values represent the mean $\pm \mathrm{SD}$ of three determinations, expressed as $\mathrm{nmol} \mathrm{O}_{2}^{\star} / \mathrm{min} / 10^{6} \mathrm{PMN}$. When included, retinol was present at a concentration of $8.8 \mu \mathrm{M}$. $p$ values reflect differences of that variable with respect to the variable after the colon.

Table 3. Inhibition of NADPH oxidoreductase by retinol added after FMLP activation of neutrophils*

\begin{tabular}{lccc}
\multicolumn{1}{c}{ Condition } & $\begin{array}{c}\mathrm{V}_{\mathrm{i}} \\
\mathrm{nmol} \mathrm{O} / \mathrm{min} / \\
10^{6} \mathrm{PMN}\end{array}$ & $\begin{array}{c}\mathrm{V}_{2-3} \\
\mathrm{nmol} \mathrm{O} \mathrm{O}_{2}^{-} / \mathrm{min} / \\
10^{6} \mathrm{PMN}\end{array}$ & $\begin{array}{c}\mathrm{V}_{2-3} / \mathrm{V}_{\mathrm{i}} \times 100 \\
(\%)\end{array}$ \\
\hline $\begin{array}{l}0.10 \mathrm{~mL} \\
\mathrm{HBSS}^{++} \text {at } 1.75 \mathrm{~min}\end{array}$ & $11.19 \pm 0.56$ & $5.48 \pm 0.55$ & $49.0 \pm 4.92$ \\
$0.10 \mathrm{~mL}$ & & $3.78 \pm 0.33$ & $28.9 \pm 2.50$ \\
$200 \mu \mathrm{M}$ retinol at $1.75 \mathrm{~min}$ & $13.09 \pm 0.28$ & & \\
\hline
\end{tabular}

* Each assay contained $5 \times 10^{5}$ PMN and was initiated by addition of $1 \mu \mathrm{M}$ FMLP final. At 1.75 min into the reaction, $0.10 \mathrm{~mL}$ of $\mathrm{HBSS}{ }^{++}$or retinol was added. $V_{i}$ was determined between $0.5-1.5$ min into the reaction. Raw $V_{2-3}$ data were corrected for dilution $(1.1 / 1.0=1.1)$. Each reaction condition reflects the mean $\pm \mathrm{SD}$ of three assays.

Table 4. Effect of retinol on $\mathrm{O}_{2}^{-}$production by crude membrane recovered from PMA-stimulated $P M N\left(\right.$ nmol $\mathrm{O}_{2}^{-} / \mathrm{min} / \mathrm{mg}$

\begin{tabular}{|c|c|c|c|}
\hline \multicolumn{4}{|c|}{ protein)* } \\
\hline & Control & Retinol $(35 \mu \mathrm{M})$ & Retinol $(70 \mu \mathrm{M})$ \\
\hline$V_{i}$ & $\begin{array}{l}255.5 \pm 23.0 \dagger \\
159.0 \pm 23.1 \dagger\end{array}$ & $\begin{array}{l}251.8 \pm 4.3 \\
156.9 \pm 27.1\end{array}$ & $\begin{array}{l}293.6 \pm 19.6 \\
217.4 \pm 32.1\end{array}$ \\
\hline$V_{2-3}$ & $\begin{array}{l}126.8 \pm 19.5 \\
114.1 \pm 11.4\end{array}$ & $\begin{array}{l}82.9 \pm 7.4(p<0.05) \\
43.4 \pm 13.5(p<0.01)\end{array}$ & $\begin{array}{l}69.7 \pm 6.5(p<0.01) \\
52.7 \pm 14.8(p<0.01)\end{array}$ \\
\hline$V_{4-5}$ & $\begin{array}{l}70.6 \pm 26.9 \\
72.5 \pm 2.5\end{array}$ & $\begin{array}{l}49.7 \pm 6.9 \\
12.5 \pm 8.3(p<0.001)\end{array}$ & $\begin{array}{l}38.4 \pm 0.4 \\
19.4 \pm 14.6(p<0.001)\end{array}$ \\
\hline
\end{tabular}

* Assays containing $100 \mu \mathrm{M}$ each of cytochrome $\mathrm{c}$ and NADPH in a total volume of 1.0 of buffer were initiated by addition of membrane. Data reflect two experiments using different membrane preparations. Each value is the mean $\pm \mathrm{SD}$ of three determinations. The $p$ values in parentheses indicate significance of difference between that value and corresponding control values.

$\dagger$ Experiment 1.

$\ddagger$ Experiment 2 .

\section{RESULTS}

Polymorphonuclear isolation and activity. PMN yield from healthy adult donors was $2.1 \pm 0.05 \times 10^{6}(n=17) \mathrm{PMN}$ per $\mathrm{mL}$ of whole blood and the NADPH oxidoreductase activity (measured as $\mathrm{V}_{\mathrm{i}}$ in the absence of retinol) was $12.14 \pm 2.34$ (range 6.68-14.10, $n=16$ ) $\mathrm{nmol}$ of $\mathrm{O}_{2}^{-} / \mathrm{min} / 10^{6} \mathrm{PMN}$.

Concentration-response data from five separate experiments are displayed collectively in Table 1, where individual and mean $\mathrm{IC}_{50}$ values reflecting the effect of retinol on intact neutrophil NADPH oxidoreductase $V_{i}, V_{2-3}$, and $V_{4-5}$ are tabulated. Over

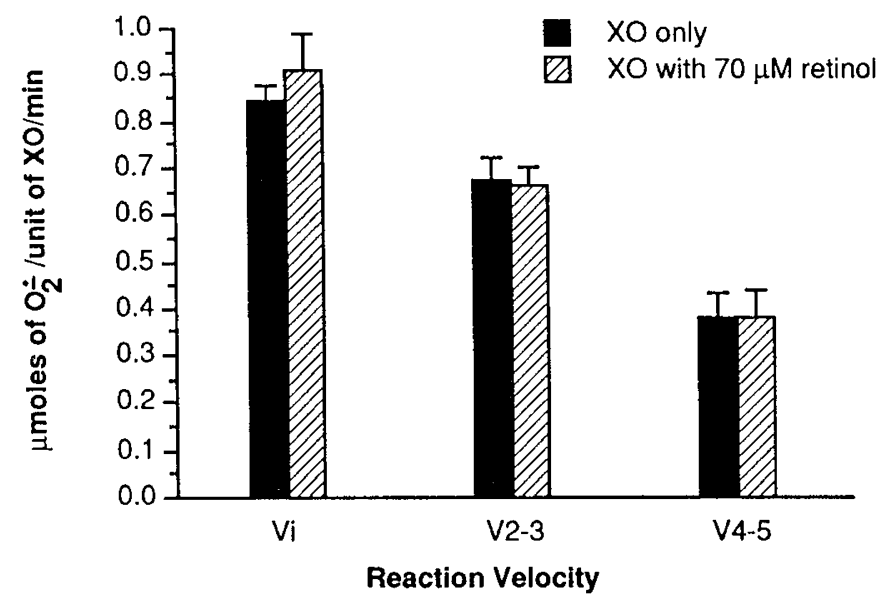

Fig. 2. Lack of effect of retinol on $\mathrm{O}_{2}^{-}$synthesis by xanthine oxidase.

the actual range of concentrations of retinol examined in these studies $(4.4-7.0 \mu \mathrm{M})$, inhibition of $\mathrm{PMN} \mathrm{O}_{2}^{-}$synthesis varied from minimal to pronounced. When the data for each experiment are normalized relative to corresponding baseline reaction velocities (no retinol, $\mathrm{V}=100 \%$ ), all the data may be combined and displayed for illustrative purposes as in Figure 1. Both Table 1 and Figure 1 indicate a steeper concentration inhibition slope for later reaction velocities $\left(\mathrm{V}_{2-3}, \mathrm{~V}_{4-5}\right)$ as compared with $\mathrm{V}_{\mathrm{i}}$. This is reflected in the lower $I_{50}$ values for $V_{2-3}$ and $V_{4-5}$ again compared to $\mathrm{V}_{\mathbf{i}}(p<0.01)$.

$\mathrm{IC}_{50}$ values noted above were established under conditions of retinol contact with PMN for only 5-7 min (the preincubation period at $37^{\circ} \mathrm{C}$ before initiation of the assay with FMLP). As detailed in Table 2, if lower concentrations of retinol (i.e. 8.8 
Table 5. Effect of brief incubation $\left(37^{\circ} \mathrm{C}, 10 \mathrm{~min}\right)$ and then washout of retinol $( \pm$ FMLP) on intact neutrophil NADPH oxidoreductase activity*

\begin{tabular}{|c|c|c|c|c|c|}
\hline & \multicolumn{5}{|c|}{ Conditions } \\
\hline & $\begin{array}{c}\text { No } \\
\text { incubation }\end{array}$ & $\begin{array}{l}\text {-Retinol } \\
\text {-FMLP }\end{array}$ & $\begin{array}{l}\text {-Retinol } \\
\text { +FMLP }\end{array}$ & $\begin{array}{l}\text { +Retinol } \\
\text {-FMLP }\end{array}$ & $\begin{array}{l}\text { +Retinol } \\
\text { +FMLP }\end{array}$ \\
\hline$V_{i}$ & $13.38 \pm 0.75$ & $\begin{array}{c}13.05 \pm 1.26 \\
(\mathrm{NS})\end{array}$ & $\begin{array}{c}13.87 \pm 1.19 \\
(\mathrm{NS})\end{array}$ & $\begin{array}{c}10.66 \pm 1.24 \\
(p<0.05)\end{array}$ & $\begin{array}{c}12.20 \pm 1.09 \\
(\mathrm{NS})\end{array}$ \\
\hline$V_{2-3}$ & $5.02 \pm 0.82$ & $\begin{array}{c}5.99 \pm 0.46 \\
(\mathrm{NS})\end{array}$ & $\begin{array}{c}6.34 \pm 0.93 \\
(\mathrm{NS})\end{array}$ & $\begin{array}{l}3.36 \pm 0.35 \\
(p<0.05)\end{array}$ & $\begin{array}{l}3.05 \pm 0.17 \\
(p<0.02)\end{array}$ \\
\hline $\mathrm{V}_{4-5}$ & $3.05 \pm 0.06$ & $\begin{array}{l}5.38 \pm 0.44 \\
(p<0.001)\end{array}$ & $\begin{array}{l}4.79 \pm 0.86 \\
(p<0.05)\end{array}$ & $\begin{array}{l}2.88 \pm 0.09 \\
(p<0.05)\end{array}$ & $\begin{array}{l}2.39 \pm 0.15 \\
(p<0.01)\end{array}$ \\
\hline
\end{tabular}

* PMN $\left(5 \times 10^{6}\right.$ in $\left.1 \mathrm{~mL}\right)$ were left gently agitated at $4^{\circ} \mathrm{C}$ (No incubation) or incubated at $37^{\circ} \mathrm{C}$ for 10 min with or without retinol $(8.8 \mu \mathrm{M}, 10$ $\min )$ and FMLP $(1 \mu \mathrm{M}, 5 \mathrm{~min})$. Thereafter, the cells were gently sedimented $\left(200 \times \mathrm{g}, 10 \mathrm{~min} 4^{\circ} \mathrm{C}\right)$ and then resuspended in HBSS for assay of FMLP-induced $\mathrm{O}_{2}^{-}$production. The $p$ values indicate differences with the indicated variable compared to cells with "No incubation."

$\mu \mathrm{M})$, ordinarily associated with minimal oxidoreductase inhibition, are incubated with PMN for longer periods of time (i.e. 60 min), significant inhibition of $\mathrm{O}_{2}^{-}$synthesis is demonstrable. More pronounced inhibition of late phases of the reaction under brief retinol contact conditions may simply reflect the longer exposure of PMN to retinol during the later part of the assay.

Table 3 indicates that even when added after FMLP activation of PMN, retinol causes significant inhibition of later phases of the reaction (here, $V_{2-3}$ ).

When FMLP was omitted from the reaction cocktail and instead retinol (final concentration 3.5-70 $\mu \mathrm{M}$ ) was added last in an attempt to initiate the PMN respiratory burst, no $\mathrm{O}_{2}^{-}$ production was appreciated. Hence, retinol in this concentration range does not appear to stimulate $\mathrm{O}_{2}^{-}$synthesis.

Retinol similarly was assessed in two separate experiments for its ability to inhibit $\mathrm{O}_{2}^{-}$production by previously PMA-activated neutrophil membrane. Table 4 indicates that $V_{i}$ was not affected, even at the highest concentrations of retinol examined. However, both $\mathrm{V}_{2-3}$ and $\mathrm{V}_{4-5}$ were inhibited significantly at both 35 and 70 $\mu \mathrm{M}$ retinol.

Inhibition of neutrophil $\mathrm{O}_{2}^{-}$production by retinol does not appear to involve free-radical scavenging action, as illustrated in Figure 2. When evaluated in conjunction with the cell-free xanthine oxidase $\mathrm{O}_{2}^{-}$-generation system, no inhibition of any reaction velocities was noted with $70 \mu \mathrm{M}$ retinol.

Possible toxic effects of retinol on intact PMN were evaluated by incubating PMN with $8.8 \mu \mathrm{M}$ retinol in the presence or absence of FMLP for $10 \mathrm{~min}, 37^{\circ} \mathrm{C}$; removing the bulk of drug from cells by centrifugation; and then reassaying the cells for FMLP-inducible oxidoreductase activity, and the supernatants for LDH activity. PMN supernatant recovered from sonicated cells demonstrated an LDH activity of $17.3 \pm 3.3 \mathrm{nmol}$ lactate oxidized $/ \mathrm{min} / 0.10 \mathrm{~mL}$ of supernatant. No LDH activity could be ascertained in any of the incubated cell supernatants. Inhibitory effect of retinol on PMN could not be eliminated by washout of the drug by centrifugation and resuspension of PMN in retinolfree media. As indicated in Table 5, once again these effects were most pronounced on later reaction velocities.

\section{DISCUSSION}

The hypothesis of our study, that vitamin A may represent an in vivo modulator of the PMN inflammatory response, supposes that in the clinical setting of BPD, vitamin A deficiency leads not only to adverse alterations in epithelial membrane structure and function, but conceivably also to impaired regulation of neutrophil activation.

Other investigators using discontinuous assay techniques have demonstrated inhibition of PMA-induced PMN chemiluminescence by retinoic acid (12); PMA-induced $\mathrm{O}_{2}^{-}$production by retinoic acid (13); and FMLP-induced $\mathrm{O}_{2}^{-}$production by retinol (14).

Our investigation differs significantly from these studies with respect to the assay system used. Because the respiratory burst is a relatively short-lived event, particularly with FMLP stimulation, a continuous assay allows examination of all phases of the reaction including activation, catalysis, and termination $(9,15$, 16). For example, later phases of the $\mathrm{O}_{2}^{-}$-generating reaction appear to be inhibited by retinol to a greater extent than initial velocity. No effect on extent of lag time after addition of the respiratory burst stimulus but before onset of $\mathrm{O}_{2}^{-}$production was appreciated in our study. Important subtleties of $\mathrm{PMN} \mathrm{O}_{2}^{-}$synthesis, like these examples, are completely ignored by discontinuous assay schemes. A continuous assay system has previously been used to examine inhibition of PMA-induced $\mathrm{O}_{2}^{-}$synthesis by retinol, retinyl acetate, and retinoic acid (17).

$\mathrm{IC}_{50}$ values $(\mu \mathrm{M})$ for retinol inhibition of FMLP-induced $\mathrm{O}_{2}^{-}$ generation derived from our study $\left(\mathrm{V}_{\mathrm{i}}, 42.6 ; \mathrm{V}_{2-3}, 21.6 ; \mathrm{V}_{4-5}\right.$, 21.7) are comparable to those generated using a discontinuous assay system with FMLP-induction $(80 \mu \mathrm{M})(14)$. Other studies have demonstrated inhibition of PMA-induced $\mathrm{O}_{2}^{-}$synthesis by various vitamin $\mathrm{A}$ metabolites including: retinoic acid (discontinuous assay), $\mathrm{IC}_{50}=45 \mu \mathrm{M}$ (12) and $100 \mu \mathrm{M}$ (13); and retinol, retinyl acetate, and retinoic acid (continuous assay), $\mathrm{IC}_{50}=200$, 200 , and $250 \mu \mathrm{M}$, respectively (17).

Using $\mathrm{O}_{2}$ consumption as an index of the PMN respiratory burst, one study claimed that low concentrations of retinoic acid $(\leq 19 \mu \mathrm{M})$ actually stimulated the respiratory burst (18). Autooxidation was noted at retinol concentrations $>80 \mu \mathrm{M}$. Although $33 \mu \mathrm{M}$ retinol and $17 \mu \mathrm{M}$ retinoic acid were reported to initiate $\mathrm{O}_{2}^{-}$production, as assessed by cytochrome $\mathrm{c}$ reduction, the data were not shown (18). When FMLP was used as a PMN activator, this same study found inhibition of $\mathrm{O}_{2}$ consumption by retinoic acid (18). Attempts in our study at stimulating the PMN respiratory burst with $3.5-7.0 \mu \mathrm{M}$ retinol were uniformly unsuccessful. Thus, mechanisms involving PMN activation (by retinol) with subsequent PMN desensitization towards FMLP are probably not operative. Inhibition of $\mathrm{PMN} \mathrm{O}_{2}^{-}$production by retinol was not explained by possible free-radical scavenging effects (Fig. 2), inasmuch as retinol did not impair cytochrome c reduction by $\mathrm{O}_{2}^{-}$in a cell-free system using xanthine and xanthine oxidase. This finding is in accord with data of other investigators $(14,17)$. Similarly, our investigation confirmed (19) that retinol in the concentrations examined did not appear to mediate PMN cytotoxicity as assessed by PMN LDH release.

Normal plasma values for retinol are in the $1-4 \mu \mathrm{M}$ range, with definite deficiency $\leq 0.3 \mu \mathrm{M}$. Toxicity can be seen at concentrations $>5 \mu \mathrm{M}$, particularly if retinol-binding protein is low. The $\mathrm{IC}_{50}$ value for retinol reported here is an order of magnitude greater than the upper limit of this normal range. But note that this $\mathrm{IC}_{50}$ value reflects only a 5-7 min interaction between retinol and the PMN. If longer periods of incubation are used, the $\mathrm{IC}_{50}$ concentration is reduced considerably (Table 2). Although our investigation established concentration-response data for exogenous retinol and its effect on the PMN respiratory burst, it did not examine the effect of exogenous retinol on the PMN retinol 
compartment. Presumably, there is a retinol equilibrium between retinol micelles or plasma transthyretin (the retinol-binding protein complex with prealbumin) and PMN retinol (membranes and intracellular retinol binding protein). Ideal experimental design would quantitate actual PMN retinol content as a function of alterations in PMN oxidative metabolism. It is conceivable that normal physiologic concentrations of retinol, in continuous equilibrium with PMN at body temperature, may exert some baseline modulatory effect on the extent of PMN activation. It is known that PMN isolated from various individuals differ significantly with respect to activity of the respiratory burst. Perhaps some of this variability relates to the in vivo concentration of vitamin A metabolites in the PMN in equilibrium with plasma.

Although the mechanism of activation of $\mathrm{PMN} \mathrm{O}_{2}^{-}$production remains incompletely understood, three phases of this process have been formulated $(20,21) ; 1)$ stimulus recognition by the PMN at cell membrane or intracellular receptors; 2) signal transduction, which involves a number of diverse events including changes in plasmalemma electrical potential, activation of phospholipases with release of fatty acids and synthesis of a variety of lipid metabolites, increased phosphoinositide turnover, enhanced calcium influx and intracellular storage release, translocation and phosphorylation of proteins, and alterations in guanosine 5'-triphosphate-binding proteins; 3) activation of the oxidase complex, which may be mediated by assembly or alteration (acylation, methylation, phosphorylation) of the components (NADPH-binding flavoprotein, cytochrome b245, ubiquinone species) Many of these events might be postulated to be sensitive to alterations in PMN retinol concentrations.

Four observations gleaned from our investigation provide clues regarding the possible mechanism of action of retinol in suppressing $\mathrm{PMN} \mathrm{O}_{2}^{-}$release. One, attempts at retinol removal (by PMN washing) after exposure to PMN does not reverse inhibition of $\mathrm{O}_{2}^{-}$production (Table 5). This likely relates to the hydrophobicity of the retinol molecule and its strong interaction with the PMN membranes or intracellular binding protein. Two, later phases of the respiratory burst are inhibited by retinol to a greater extent than $V_{\mathrm{i}}$. This may simply relate to length of exposure of the PMN to retinol (Table 2) relative to the rate constant for achieving equilibrium between exogenous and PMN retinol. Three, even when added after the respiratory burst stimulus (FMLP), retinol can still restrain $\mathrm{PMN} \mathrm{O}_{2}^{-}$production (Table 3 ). Four, retinol inhibits $\mathrm{O}_{2}^{-}$generation even in previously activated PMN membrane. In this situation, initial velocity is unaffected, but later reaction phases are significantly inhibited (Table 4).

Retinol $(35-70 \mu \mathrm{M})$ has been shown to induce erythrocyte membrane perturbations characterized by plasmalemma indentations and vacuolizations (22). It is known that activation of the PMN respiratory burst is associated with alterations in membrane fluidity (19) and phospholipid remodeling (23), as well as possible translocation of the oxidoreductase complex components. It is possible that retinol affects the dynamic properties of the plasma membrane of activated PMN such as the association of the various respiratory burst oxidoreductase components $(20$, $21,24,25)$. Retinol suspended in an aqueous solvent, perhaps in the form of micelles, likely requires time (minutes) to effectively interact with the PMN, thus accounting for the more pronounced effects on later respiratory burst reaction velocities. In the case of an activated respiratory burst complex (activated PMN membrane), retinol may act by promoting complex dissociation, hence the effect on $\mathrm{V}_{2-3}$ and $\mathrm{V}_{4-5}$, but not $\mathrm{V}_{\mathrm{i}}$. In addition to inhibiting $\mathrm{O}_{2}^{-}$release, previous investigators have also demonstrated that retinoids inhibit the exocytosis of granule enzymes such as lysosome and $\beta$-glucuronidase. Hence, the effect of these compounds is not specific to oxyradical metabolism (19).

Retinol may affect the expression of genes or gene products (26). Activation of the respiratory burst does not involve transcription or translation. Moreover, effects on these processes (by retinol) would be expected to require hours, not minutes. It has been stated that retinol may directly inhibit PMN PK-C $(17,27)$. Moreover phosphorylation of oxidoreductase components may be required for activation $(20,21)$. PMN activation by PMA follows PK-C activation (21). In the presence of retinol, PK-C activation and $\mathrm{O}_{2}^{-}$production are concomitantly inhibited (28). PMN activation by the receptor ligand FMLP, however, involves other signal transduction in addition to $\mathrm{PK}-\mathrm{C}$ activation, (e.g. calmodulin-dependent kinase) (20). Hence, inhibition of PK-C by retinol is not sufficient to explain retinol's effect on FMLPinduced PMN.

Retinoids have been termed "labilizers of lysosomes" (14) because of their tendency to increase lysosomal fragility. NADPH oxidoreductase $\left(\mathrm{O}_{2}^{-}\right.$synthetase $)$is known to be exquisitely sensitive to endogenous PMN proteases (29). Release of proteases from PMN granules by retinol could perhaps explain its inhibitory effect on $\mathrm{O}_{2}^{-}$production.

Alterations in PMN membrane fluidity and permeability by retinol might result in other aberrations such as altered FMLP receptor conformation or increased calcium influx leading to permanent depolarization. Higher concentrations of receptor agonist (FMLP) might reverse some of the retinol inhibition and thus implicate this receptor as a specific target of retinol.

If retinol works through a depolarizing mechanism, transient activation of $\mathrm{O}_{2}^{-}$synthesis might be expected, followed by inhibition. Activation of $\mathrm{O}_{2}^{-}$synthesis by retinol was not observed in our investigation, but has been reported by others (18).

Use of adult rather than neonatal PMN in our study was rationalized by the observation that neonatal and adult PMN are essentially identical with respect to qualitative and quantitative aspects of the respiratory burst $(16,30)$. Assuming a yield of $2 \times$ $10^{6} \mathrm{PMN}$ per $\mathrm{mL}$ of blood, $15-30 \mathrm{~mL}$ of blood was required for each of the individual experiments in our investigation. Obtaining this amount of blood from neonates $(5-10 \%$ of total blood volume of a $4-\mathrm{kg}$ infant) could not be justified. However, it would be of great interest to assay the respiratory burst in vitamin A-deficient PMN obtained from vitamin A-deficient infants (presumably at risk to develop BPD) compared with vitamin Asufficient infants.

Vitamin A metabolites play an essential role in regulating various aspects of epithelial structure and function $(1-3,26)$. Deficiency of vitamin $A$ in the setting of respiratory distress syndrome and iatrogenic-induced primary pulmonary injury may impair airway healing and contribute to the pathogenesis of BPD. Based on the results of our in vitro study, it is intriguing to speculate that the major vitamin A derivative, retinol, at physiologic levels, may orchestrate modulation of the PMN inflammatory response. Insuring adequate vitamin A levels in BPD-susceptible infants may be important for a number of positive effects. Further elucidation of the precise action of retinoids on PMN metabolism will help define their role in the clinical setting.

\section{REFERENCES}

1. Hustead VA, Gutcher GR, Anderson SA, Zachman RD 1984 Relationship of vitamin $\mathrm{A}$ (retinol) status to lung disease in the premature infant. $\mathrm{J}$ Pediatr 105:610-615

2. Shenai JP, Chytil F, Stahlman MT 1985 Vitamin A status of neonates with bronchopulmonary dysplasia. Pediatr Res 19:185-189

3. Zachman RD 1989 Retinol (vitamin A) and the neonate: special problems of the human premature neonate. Am J Clin Nutr 50:413-424

4. Ogden BE, Murphy S, Saunders GC, Johnson J 1983 Lung lavage of newborns with respiratory distress syndrome. Prolonged neutrophil influx is associated with bronchopulmonary dysplasia. Chest $83: 31 \mathrm{~S}-33 \mathrm{~S}$

5. Merritt TA, Cochrane CG, Holcomb K, Bohl B, Hallman M, Strayer D, Edwards DK, Gluck L 1983 Elastase and $\alpha_{1}$-proteinase inhibitory activity in tracheal aspirates during respiratory distress syndrome. J Clin Invest 72:656666

6. Bruce MC, Wedig KE, Jentoff N, Martin RJ, Cheng P-W, Boat TF, Fanaroff AA 1985 Altered urinary excretion of elastin cross-links in premature infants who develop bronchopulmonary dysplasia. Am Res Respir Dis 131:568-572

7. Zimmerman JJ 1988 Oxyradical species and their relationship to pathophysiology in pediatric critical care illness. Crit Care Clin 4:645-660

8. Ferrante A, Thong YH 1980 Optimal conditions for simultaneous purification 
of mononuclear and polymorphonuclear leukocytes from human blood by the Hypaque-Ficoll method. J Immunol Methods 36:109-117

9. Zimmerman JJ, Shelhamer JH, Parrillo JE 1985 Examination of the enzyme assay for NADPH oxidoreductase; application to polymorphonuclear leukocyte superoxide anion generation. Crit Care Med 13:197-203

10. McCord JM, Fridovich I 1968 Reduction of cytochrome c by milk xanthine oxidase. J Biol Chem 243:5753-5760

11. Wacker WEC, Ulmer DD, Vallee BL 1956 Metalloenzymes and myocardial infarction. Malic and lactic dehydrogenase activities and zinc concentrations in serum. N Engl J Med 255:449-456

12. Kensler TW, Trush MA 1981 Inhibition of phorbol ester-stimulated chemiluminescence in human polymorphonuclear leukocytes by retinoic acid and 5,6-epoxyretinoic acid. Cancer Res 41:216-220

13. Wolfson M, Shinwell ES, Zvillich M, Rager-Zisman B 1988 Inhibitory effect of retinoic acid on the respiratory burst of adult and cord blood neutrophils and macrophages: potential implication to bronchopulmonary dysplasia. Clin Exp Immunol 72:505-509

14. Camisa C, Eisenstat B, Ragaz A, Weissmann G 1982 The effects of retinoids on neutrophil functions in vitro. J Am Acad Dermatol 6:620-629

15. Light DR, Walsh C, O'Callaghan AM, Goetzl EJ, Tauber AI 1981 Characteristics of the cofactor requirements for the superoxide-generating NADPH oxidase of human polymorphonuclear leukocytes. Biochemistry 20:14681476

16. Strauss RG, Snyder EL 1983 Activation and activity of superoxide-generating system of neutrophils from human infants. Pediatr Res 17:662-664

17. Witz G, Goldstein BD, Amoruso M, Stone DS, Troll W 1980 Retinoid inhibition of superoxide anion radical production by human polymorphonuclear leukocytes stimulated with tumor promoters. Biochem Biophys Res Commun 97:883-888
18. Hemila H, Wikstrom M 1985 Retinoids activate superoxide production by polymorphonuclear leukocytes. Scand J Immunol 21:227-234

19. Weissmann G, Smolen JE, Korchak HM 1980 Release of inflammatory mediators from stimulated neutrophils. N Engl J Med 303:27-34

20. Rossi $\mathrm{F} 1986$ The $\mathrm{O}_{2}^{-}$-forming NADPH oxidase of phagocytes: nature, mechanisms of activation and function. Biochim Biophys Acta 853:65-89

21. Tauber AI 1987 Protein kinase $C$ and the activation of the human neutrophil NADPH-oxidase. Blood 69:711-720

22. Dingle JT, Lucy JA 1962 Studies on the mode of action of excess vitamin A 5 . The effect of vitamin $A$ on the stability of the erythrocyte. Biochem $J$ 84:611-621

23. Reinhold SL, Zimmerman GA, Prescott SM, McIntyre TM 1989 Phospholipid remodeling in human neutrophils. J Biol Chem 264:21652-21659

24. Ohno Y, Seligmann BE, Gallin JI 1985 Cytochrome b translocation to human neutrophil plasma membranes and superoxide release. J Biol Chem 260:2409-2414

25. Wolfson M, McPhail LC, Nasrollah VN, Snyderman R 1985 Phorbol myristate acetate mediates redistribution of protein kinase $C$ in human neutrophils: potential role in the activation of the respiratory burst enzyme. J Immunol 35:2057-2062

26. Goodman DS 1984 Vitamin A and retinoids in health and disease. N Engl J Med 310:1023-1031

27. Taffet SM, Greenfield ARL, Haddox MK 1983 Retinal inhibits TPA-activated calcium-dependent phospholipid dependent protein kinase ("C" kinase) Biochem Biophys Res Commun 1 14:1194-1199

28. Cooke E, Hallett MB 1985 The role of C-kinase the physiologic activation of the neutrophil oxidase. Biochem J 232:323-327

29. Markert M, Glass GA, Babior BM 1985 Respiratory burst oxidase from human neutrophils: purification and some properties. Proc Natl Acad Sci USA 82:3144-3148

30. Newburger PE 1982 Superoxide generation by human fetal granulocytes. Pediatr Res 16:373-376 